ENTREPRENEURSHIP AND SUSTAINABILITY ISSUES

ISSN 2345-0282 (online) http://jssidoi.org/jesi/

2021 Volume 8 Number 3 (March)

http://doi.org/10.9770/jesi.2021.8.3(28)
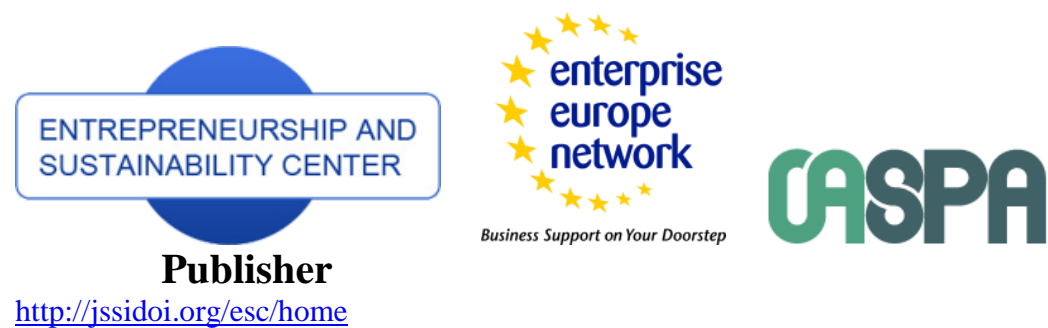

Business Support on Your Doorstep

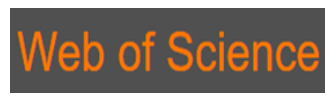

http://jssidoi.org/esc/home

1 Clarivate

Analytics

\title{
THE ROLE OF A DEFENCE INDUSTRY IN THE SYSTEM OF NATIONAL SECURITY: A CASE STUDY
}

\author{
Oleksandr Ilchenko ${ }^{1}$, Oksana Brusakova ${ }^{2}$, Yuliia Burchenko ${ }^{3}$, Artem Yaroshenko ${ }^{4}$, Yaroslav Bagan 5 \\ ${ }^{1 * S u m y ~ S t a t e}$ University, 2 Rimsky-Korsakova Street, Sumy, 40000, Ukraine \\ ${ }^{2}$ Kharkiv National University of Internal Affairs, Lev Landau Avenue, 27, Kharkiv, 61000, Ukraine \\ ${ }^{3}$ National University of Water Management and Nature Management, Soborna Street, 11, Rivne, 33000, Ukraine \\ ${ }^{4}$ Dnipropetrovsk State University of Internal Affairs, Ave. Gagarina, 26, 49005, Dnipro, Ukraine \\ ${ }^{5}$ Law firm "Ex Jure", Sh. Rustaveli str., 18, Lviv, 79005, Ukraine \\ E-mail: ${ }^{{ }^{*}} \underline{\text { ilchenko@fm.ua }}$
}

Received 15 March 2020 ; accepted 10 December 2020; published 30 March 2021

\begin{abstract}
It was determined that the existing scientific and methodological approaches to the assessment of the state of financial security of defence industry enterprises due to the specific peculiarities of this industry and the rapid changes in their external environment, currently taking place, need both the advancement in the direction of improving the level of timeliness of such assessment and expansion of the indicators list for its implementation. In the light of modern conditions, characterized by globalization and increased competition in the domestic and foreign arms markets, the defence enterprises can be competitive if they can adapt their activity effectively to the changes in the external environment, take timely preventive measures against the impact of negative environmental factors and make timely use of the opportunities, provided by the environment for strengthening of their financial security. In the research, the authors have improved scientific and methodological approaches to the complex assessment of financial security of defence enterprises - conduction of the analysis upon 3 blocks: definition of the indicators system (including the one upon the criterion of the enterprise's relations state with the subjects of the external environment; express diagnostics of the enterprise's financial security; a full-blown assessment of the financial security of the enterprise, which makes it possible to provide operational efficiency during substantiation of the administrative decisions, concerning the provision of financial security of the enterprises and consider the change of conditions of their interaction with subjects of the external environment. The development of the integration processes in the global economy, in particular defence industries, and the steady increase in competition on the global arms market, provides importers of arms and military equipment (AME) with a diverse choice of means of pressure on the exporters, directly encourage the application of the offset practices in this area. The research determines the ways and priorities of application of the offset activity by defence enterprises of Ukraine in the context of consideration of this phenomenon as a tool for strengthening their financial security thanks to the optimization of expenditures for implementation of the exportimport operations and research, development, and engineering activity (RD\&T).
\end{abstract}

Keywords: national security; financial security; defence industry; offset activity; express diagnostics; Ukraine

Reference to this paper should be made as follows: Ilchenko, O., Brusakova, O., Burchenko, Y., Yaroshenko, A., Bagan, Y. 2021. The role of a defence industry in the system of national security: a case study. Entrepreneurship and Sustainability Issues, 8(3), 438-454. http://doi.org/10.9770/jesi.2021.8.3(28)

JEL Classifications: F35, F42 


\section{ENTREPRENEURSHIP AND SUSTAINABILITY ISSUES}

ISSN 2345-0282 (online) http://jssidoi.org/jesi/

2021 Volume 8 Number 3 (March)

http://doi.org/10.9770/jesi.2021.8.3(28)

Make your research more visible, join the Twitter account of ENTREPRENEURSHIP AND SUSTAINABILITY ISSUES: @Entrepr69728810

\section{Introduction}

The world market experience shows that the dynamic growth of the sovereign country, which can guarantee security to its residents, is not possible without functioning of the defence industry. It is impossible to provide state security without the Armed Forces and the defence industry, catering to its needs, in the light of instability of the international environment. The existence of strong defence industry is also the key success factor to the reinforcement of the international cooperation of any country: provision of conditions for its full participation in the collective security systems and systems of control over the supply of defence and dual-purpose products and technologies.

The manufacturing sector of the defence economy plays a decisive role in the production and supply of the military products to the Armed Forces and other military formations. It is a special part of the state's economy, catering to its specific military and economic needs for national security provision. Among such needs are arming, ammunition supplies, military machinery, other military property, spare parts and materials, the performance of activities and provision of services, as well as export-import delivery in the area of the military and technical cooperation of Ukraine with foreign countries.

The fundamental principles of satisfying the military and technical needs of the Armed Forces include the achievement of compliance of the level of their technical equipment with the national security needs of the state; consideration of scientific, technical, and economic capabilities of the state; maintenance of the armaments, military, special equipment and other property in readiness condition.

The Military-Industrial Complex/Defence industry is the key element in the production sector of the defence economy of the developed countries. In Ukraine, it is the defence industrial complex (hereinafter referred to as the "DIC") as an integral economic system of industries, enterprises, scientific organizations, design bureaus and service facilities of the infrastructure of this system, focusing on research, development, production, and supply of weapons, military and special equipment and property for satisfaction of the national military-economic needs.

The defence industry is critical to both the development of the national economy and the protection of public interests. Successful functioning of this strategic state industry requires specific grounded economic policy (Rajnoha, R. et al., 2019; Liao, H. et al., 2019; Lincényi, M. \& Čársky, J. 2020). It is an area that nowadays operates mainly within the industry 4.0; what triggers respective specific threats, which have to be addressed at national and international level (Tvaronavičienè, M. et al., 2020; Plèta et al., 2020).

The regulation of the defence-industrial complex development, which can adapt to functioning in crises situations and threats to national security, ensure the transition to the fifth technological mode and strengthen the state's ability within the framework of achieving military and political independence by Ukraine, meets the national interests of Ukraine.

\section{Literature Survey}

The international practices of the world's leading countries, including Central and Eastern European countries, also indicate about the use of the diverse mechanisms for the attraction of financial resources to the defence industry, namely:

- arrangement of favourable investment conditions by granting allowances and preferences to the defence enterprises through the adoption of the consistent normative legal acts (Qureshi, F.A. (2018)); 


\section{ENTREPRENEURSHIP AND SUSTAINABILITY ISSUES}

ISSN 2345-0282 (online) http://jssidoi.org/jesi/

2021 Volume 8 Number 3 (March)

http://doi.org/10.9770/jesi.2021.8.3(28)

Make your research more visible, join the Twitter account of ENTREPRENEURSHIP AND SUSTAINABILITY ISSUES: @Entrepr69728810

- maintenance of cooperation with foreign enterprises, including the one, conducted through the establishment of joint ventures, without sacrificing state control over strategic enterprises (sales of no more than $25-49 \%$ of shares) (Behma, V.M., \& Sverhunov, O.O. (2019));

- vigorous activity in stock markets. The analysis of the activity of the world-leading arms producers shows that a stock market is one of the most significant sources for the attraction of the investments, while the growth of capitalization of these enterprises is one of the fundamental criteria of their economic success (Lonsdale, D.J. (2019));

- the last few years have been marked by new tendencies in the offset policy. The main tendencies of the modern world in the area of offset can be regarded as follows (Nzeribe, S., \& Imam, M. (2018); Kravchenko, V. (2019); Usachenko, O. (2019)): an increase in the number of countries that apply offset when purchasing the military purpose products; the growing importance of the offset programs in the tender holding; the increase in the role and share of the projects on direct offset in the development of the offset programs; the increase in the volume of the offset obligations to $100 \%$ and more from the contract cost for delivery of the defence and military goods (DMG); the importers' insisting, in the framework of indirect offset, first of all, on transference to them the knowledge-intensive technologies, developments, and "know-how" of the military, dual- and civilian purpose, on conduction of joint scientific research and training of the qualified scientific staff; the reduction in the size of multipliers (multiplying coefficient) in the determination of the offset value of the projects; the attempts to limit the transfer of critical technologies on arms production.

The main principles of government export regulation of military technologies should be as follows:

- provision of the correspondence of the state regulatory methods to the national security needs (Avanesova, N.E., Kolodyazhna, T.V., \& Semenova, J.I. (2018));

- the use of scientific methods for determination of the economic practicality of the military technologies export (Momot, T.V., Avanesova, N.E., \& Vinnik, I.U. (2015));

- optimal combination of instruments for limiting and encouraging of the military technologies export (Potomkina, M. (2018));

- implementation of measures or state regulation of military technologies export, based on the creation of an appropriate regulatory framework and strict control over compliance with such a foundation (Kamianetska, O. (2015));

- encouragement of the establishment and use of an individual system of intra-company export control by the corporate exporters (Reznik O., Mazievich T., Shebanits D., Puzanova G., Pyrih I. (2020));

- establishment of a high level of responsibility (including criminal liability) for non-compliance with the statutory requirements of the system of state regulation over the military technologies export (Weber, R.N. (2020)).

In paying tribute to the scientific and practical significance of the works of these authors, it should be noted that some questions of a theoretical and methodological nature have not been sufficiently studied, namely: interdependence between the state of financial security of defence enterprises and the degree of realization of national interests, influence on the development of risks and threats to the economic security of the state; identification of opportunities and problems in the provision of the financial security of the enterprises in their interaction with the external environment; the existing approaches to assessing the level of defence enterprises' financial security do not sufficiently consider the dynamics and the interrelation of factors, predetermining it; insufficient consideration of specific peculiarities of the subjects of the external environment of the defence enterprises. 
ENTREPRENEURSHIP AND SUSTAINABILITY ISSUES

ISSN 2345-0282 (online) http://jssidoi.org/jesi/

2021 Volume 8 Number 3 (March)

http://doi.org/10.9770/jesi.2021.8.3(28)

Make your research more visible, join the Twitter account of ENTREPRENEURSHIP AND SUSTAINABILITY ISSUES: @Entrepr69728810

\section{Methods}

The research included the following methods of scientific cognition: observation, analysis of empirical science, logical generalization - for determining the place and role of the defence industry in the realization of the national interests; analysis and synthesis, comparison, structural-logical and semantic analysis - during the study of the content and peculiarities of the financial security of the highlighted companies, as well as its impact on the components of the economic security of the state; systemic and subject-oriented approach - during substantiation of theoretical formation foundations of a mechanism and tools for provision of financial security of the defence industry enterprises in interaction with the subjects of the external environment; comparative analysis - during the process of researching the international experience on the development of the defence industry in the context of its implementation in Ukraine; multi-criteria (vector) optimization, economics and mathematics (analysis and simulation) modelling - when substantiating the scientific-methodological approach to modeling and multicriteria optimization of financial and material flows at the defence industry enterprises.

\section{Results}

The results of the analysis show that during the period from 2014 to 2018, the number of the enterprises and DIC organizations in Ukraine fell five-fold, while the number of employees - decreased by a factor of 7 times (in particular, the employees of the 35-45 age group) (State Statistics Service of Ukraine). The average age of qualified specialists is $40-65$.

The analysis of the existing approaches towards the assessment of different aspects of financial safety of the defensive industry enterprises has confirmed that there is an urgent need for advancement and introduction of the integrated rating approaches to financial safety condition assessment of the highlighted enterprises, which levels lack existing approaches and will raise their adequacy to modern market conditions, including, first of all, expansion of the enterprises' spectrum of interaction with the external environment.

The results of the author's express diagnostics of financial security condition of 12 Ukrainian defence enterprises (3 non-governmental enterprises (private), 9 - state enterprises), held based on their statistical data (upon the data available as of 01.01.2019) with consideration of analysis, are given in Table 1. 


\section{ENTREPRENEURSHIP AND SUSTAINABILITY ISSUES}

ISSN 2345-0282 (online) http://jssidoi.org/jesi/

2021 Volume 8 Number 3 (March)

http://doi.org/10.9770/jesi.2021.8.3(28)

Make your research more visible, join the Twitter account of ENTREPRENEURSHIP AND SUSTAINABILITY ISSUES: @ Entrepr69728810

Table 1. The results of the integrated index of the express diagnostics of the defence enterprises' financial security condition in Ukraine for 2014-2018

\begin{tabular}{|c|c|c|c|c|c|}
\hline Enterprise & 2014 & 2015 & 2016 & 2017 & 2018 \\
\hline \multicolumn{6}{|c|}{ Private enterprises } \\
\hline Private Joint Stock Company "FED" & 2,3 & 2,4 & 2,7 & 2,5 & 3,0 \\
\hline Public Joint Stock Company “Motor Sich” & 3,3 & 3,4 & 3,4 & 2,9 & 3,2 \\
\hline Private Stock Company "Plant "Kuznya on Rybalsky" & 1,9 & 1,8 & 1,8 & 2,1 & 2,4 \\
\hline \multicolumn{6}{|c|}{ State enterprises } \\
\hline \multicolumn{6}{|c|}{ The cluster of armoured and automotive engineering } \\
\hline State Enterprise "Kharkiv Plant of Armored Tanks" (SE KPAT) & 1,9 & 2,3 & 3,6 & 3,0 & 3,3 \\
\hline State Enterprise "Lviv Armored Fighting Vehicle Plant" (SE LAFVP) & 3,6 & 2,7 & 2,4 & 1,7 & 1,4 \\
\hline State Enterprise "Kyiv Armored Plant" (SE KAP) & 3,0 & 3,2 & 2,2 & 2,6 & 3,0 \\
\hline State Enterprise "Malyshev Plant" & 1,6 & 1,5 & 1,3 & 1,8 & 3,0 \\
\hline State Enterprise "Kharkiv Automobile Repair Plant" (SE KARRP) & 1,6 & 1,9 & 3,8 & 2,0 & 3,0 \\
\hline \multicolumn{6}{|c|}{ The cluster of aircraft construction and aircraft repair } \\
\hline State Enterprise "Lviv State Aircraft Repair Plant" (SE LSARP) & 3,4 & 3,2 & 3,0 & 3,4 & 3,2 \\
\hline \multicolumn{6}{|c|}{ The cluster of high-precision weaponry and ammunition } \\
\hline State Enterprise "State Kyiv Design Bureau "Luch” (SE SKDB “Luch”) & 2,5 & 2,9 & 2,9 & 2,7 & 2,7 \\
\hline State Joint Stock Holding Company “Artem" & 2,9 & 2,0 & 2,2 & 2,8 & 2,3 \\
\hline \multicolumn{6}{|c|}{ The cluster of radiolocation, radio communication, and anti-aircraft defence systems } \\
\hline State Enterprise "Lviv Radio Repair Plant" (SE LRRP) & 3,4 & 3,2 & 3,0 & 3,4 & 3,2 \\
\hline
\end{tabular}

Source: compiled by the author based on the data of YouControl system is an online service

The evaluation findings show that with the beginning of the hybrid war against Ukraine, the state defence enterprises have significantly improved the level of their financial security: almost all of the enterprises under the study in 2017-2018 reached high and satisfactory levels. The only exception in the cluster of armoured and automotive engineering is State Enterprise "Lviv Armored Fighting Vehicle Plant," the level of financial security of which during 2014-2018 was at a critical level due to systemic failures of the government's defence orders execution due to "flexible" corruption scandals and stops of financing (seizure of accounts).

By contrast, the other companies in this group had the most stable financial security situation, in particular, at State Enterprise "Kyiv Armored Plant" and State Enterprise "Kharkiv Plant of Armored Tanks." Thanks to their active interaction with the external environment: the enterprise SE KPAT expands the scale of services on mechanical maintenance, while SE KAP, apart from that, constantly puts the export contracts into action.

State Enterprise "Malyshev Plant" is another enterprise, producing armoured products in Ukraine. In recent years, it has been in crisis due to the inadequacy of existing production capacity with real production orders. Nonetheless, the implementation of the export contract with Thailand in 2017 allowed it to improve the situation and achieve a satisfactory level of financial security. 


\section{ENTREPRENEURSHIP AND SUSTAINABILITY ISSUES}

ISSN 2345-0282 (online) http://jssidoi.org/jesi/

2021 Volume 8 Number 3 (March)

http://doi.org/10.9770/jesi.2021.8.3(28)

Make your research more visible, join the Twitter account of ENTREPRENEURSHIP AND SUSTAINABILITY ISSUES: @Entrepr69728810

State Enterprise "Kharkiv Automobile Repair Plant" takes a separate position in the range of enterprises under the study. In recent years, the level of its financial security has fluctuated from critical to high because this enterprise practically does not receive any state orders for repair of the military equipment. Moreover, it has no access to foreign markets. Thus, it is forced to work in competitive conditions with private companies in the domestic car repair market.

The next group of traditionally stable state defence enterprises in recent years includes State Enterprise "Lviv Radio Repair Plant" (a cluster of radiolocation, radio communication and anti-aircraft defence systems) and State Enterprise "Lviv State Aircraft Repair Plant" (a cluster of aircraft construction and aircraft repair). The level of financial security of these enterprises ranges from satisfactory to high due to their practically monopolistic position on the domestic arms market and active position on the foreign market.

To this group of stable enterprises, in terms of financial security, one can also include the enterprise of the highprecision weaponry and ammunition cluster: State Enterprise "State Kiev Design Bureau "Luch" (its level of financial security over the last 5 years is regarded as satisfactory). It can be listed in this group as a result of the additional organization of independent production of defence products of its own design at a traditionally scientific and design enterprise. The majority of the mentioned products should be produced at the production capacities of State Joint Stock Holding Company "Artem," as it specializes in the production of high-technology defence products; with which SE SKDB "Luch" is in partnership. This, alongside more vigorous activity on foreign markets and solution of problems with import substitution of components, would allow SJSHC "Artem" to improve the level of financial security to a satisfactory one (as of today, this company sits at the nonsatisfactory level of financial security).

In general, in the group of state enterprises of the defence industry, one traces the influence of the extent of application of active cooperation by the enterprises with the external environment (export and import contracts, partnerships with suppliers and consumers, lobbying in relations with the state, etc.) on the level of their financial security. Different levels of financial security at the enterprises under consideration result from their industry specificity, which ha differences in the legal regulation of the industry, existing business practices, organizational peculiarities of the enterprises, technological peculiarities of production (in particular, the availability and complexity of cooperative relationships), market demand, and modern needs of the Armed Forces of Ukraine, the degree of state regulation of activity, etc.

In the group of considered private companies of the defence industry of Ukraine, there is a stable high level of financial security of large enterprises: Public Joint Stock Company "Motor Sich" and Private Joint Stock Company "FED." PJSC "Motor Sich" is the undisputed leader among them. The level of its financial security was at a high level during 4 of 5 years due to its better adaptation to market conditions, compared to the state enterprises. The previously-mentioned enterprise actively interacts with the external environment (in particular, it exports to over 100 countries and has complex cooperation links, including the EU enterprises).

PJSC "FED" has also been at a satisfactory level of financial security in recent years, primarily, due to the use of extensive cooperative ties during the sale of products and performance of the export activity with competitive products of its own production. Private Stock Company "Plant "Kuznya on Rybalsky" in 2013-2014 was in a state of crisis due to passive adaptation to market conditions (the enterprise offered a limited range of services). At the same time, over the last 2 years, this enterprise has actively joined the state defence order on the production of 
Make your research more visible, join the Twitter account of ENTREPRENEURSHIP AND SUSTAINABILITY ISSUES: @Entrepr69728810

armoured personnel carriers for the Ukrainian Navy, thanks to which, the level of its financial security has increased, but has not yet exceeded the limits of the unsatisfactory level.

In general, there is a positive trend in the group of private enterprises of the Ukrainian defence industry to increase in their active participation in the production of defence products (which is a worldwide trend), including by means of the state defence order, which improves their financial situation and enhances financial security. Alongside this, there is a direct dependence of the state of financial security of these companies on their management level and the ability for a preventive response to the changes in the external environment, including, through the establishment of productive cooperation with its subjects. Figure 1 illustrates the dynamics of the production profitability of goods of the industrial enterprises.

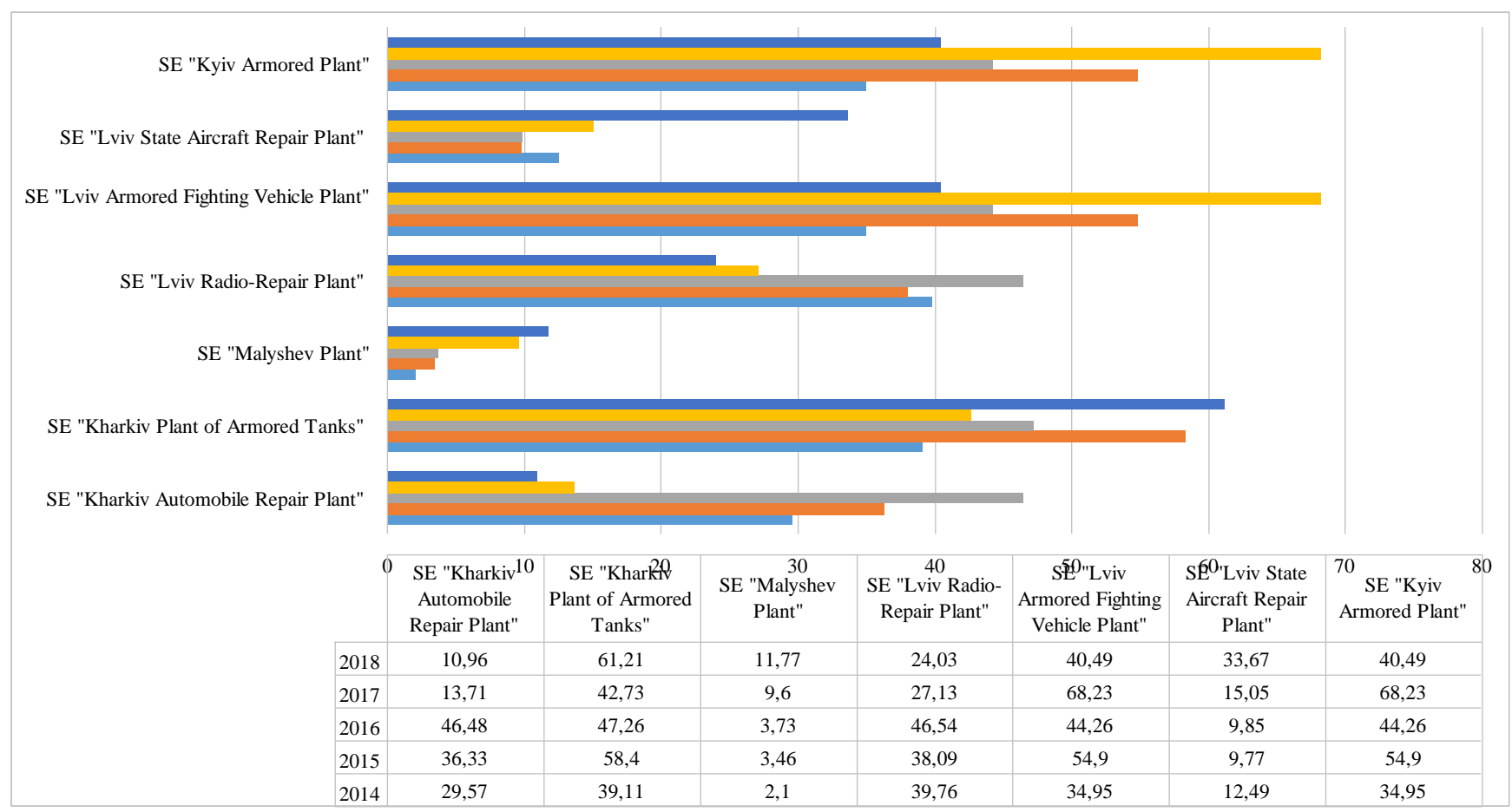

Figure 1. Dynamics of production profitability of goods of state enterprises in the defence industry in Ukraine during 2014-2018 Source: compiled by the author based on the data of State Statistics Service of Ukraine

Thus, one can conclude that production profitability of the state enterprises of the defence industry in Ukraine during 2014-2018 is gradually reducing, except for SE "Kharkiv Plant of Armored Tanks."

In this regard, the problem of objective price formation for the military purpose products (MPP) takes on particular significance. The cost of the Customer's mistake in the question of price formation is very high and leads to inefficient use of limited financial resources of the state and decrease in financial security at the enterprises.

Thus, if the planned cost in the state programs and the state defence order (SDO) is lower than the actual cost, the ordering authorities will have to review the previously drawn up defence and military goods plans (DMG) or 


\section{ENTREPRENEURSHIP AND SUSTAINABILITY ISSUES}

ISSN 2345-0282 (online) http://jssidoi.org/jesi/

2021 Volume 8 Number 3 (March)

http://doi.org/10.9770/jesi.2021.8.3(28)

Make your research more visible, join the Twitter account of ENTREPRENEURSHIP AND SUSTAINABILITY ISSUES: @Entrepr69728810

refuse to purchase DMG, which will destabilize the DMG development plans and have negatively affected the combat readiness of the armed forces, the state of DIC enterprises, and, consequently, on national security.

Hence, the quality of development of the conceptual framework and the regulatory and methodological apparatus, concerning the DMG price justification is a necessary condition for achievement of the goals on the provision of the financial security of the DIC enterprises and the state.

The actual order of formation of the price for the production, works, services of defence appointment in Ukraine (in case selection of executors on supply (purchase) of such production, works, services is carried out without application of competitive procedures) was introduced by the Decree of the Cabinet of Ministers of Ukraine dated August 8, 2016, No. 517. (About the statement of the Order of formation of the price for production, works, services of defence appointment in case selection of executors on supply (purchase) of such production, works, services is carried out without application of competitive procedures (2016)).

According to it, the profit or the enterprise as a part of the price should not exceed $5 \%$ of its expenditures on the purchase of components (semi-finished products) and works (services) from other business entities, as well as $30 \%$ of other expenses in the production cost of products (works, services) of own production.

In reality, the percentage of purchased components (semifinished piece) in the latest DMG samples amounts, on average, $70 \%$ of the total number, while the rest number (own production) amounts only $30 \%$, which affects the level of profit. Currently, the defence industry enterprises have an estimated profit level of $10 \%$, while the real profit level is even lower, considering the inflation temps.

The established profit level significantly limits opportunities for the development of the military purpose products producers. Despite this, to save financial resources, allocated for the purchase of weapons and military machinery, the Ministry of Defence of Ukraine approved "Methodological recommendations, for unified approaches during application of certain provisions, determined by the decision of the Cabinet of Ministers of Ukraine №517 dated 08.08.2016" (upon the registered number 2591/u/2 of 18.10.2016), where the determined profit levels $(5 \%$ and $30 \%$ ) were reduced (About the statement of the Order of formation of the price for production, works, services of defence appointment in case selection of executors on supply (purchase) of such production, works, services is carried out without application of competitive procedures (2016)).

Thus, the Methodological recommendations reduced the acceptable level of profit, amounted to expenses from the purchase of components (semifinished products), works (services) from other business entities fivefold - from 5\% to $1 \%$, while the profit level for the rest of expenses - was reduced from $30 \%$ to $20 \%$.

Thus, according to the standards, specified by the Methodological recommendations, the estimated profitability level of the executor of the State defence order was reduced for almost two times - to 5.4-8\% (which is less than even the planned inflation rate in Ukraine) (About the statement of the Order of formation of the price for production, works, services of defence appointment in case selection of executors on supply (purchase) of such production, works, services is carried out without application of competitive procedures (2016)).

When studying the international experience on price formation, one gets an opportunity to identify its regularities and trends, and the use of the received knowledge during the formation and regulation of prices for MPP. 
In foreign countries with the developed market and mixed economies, the sphere of regulated and controlled by the state pricing accounts from 10 to $40 \%$ of the total of output. Thus, the percentage of prices, controlled and regulated by the state, in Austria reaches $10 \%$, in Germany - up to 40\%, Greece - 20\%, in Denmark - 5\%, Spain - $10 \%$, in Italy - up to $30 \%$, China - up to $30 \%$, USA - up to $10 \%$, France - 20\%, Finland - up to $40 \%$, Sweden up to $40 \%$, Japan - up to $20 \%$ (Official website of the Department of Homeland Security USA). While analyzing the methods, used by the world countries, let us group them and characterize each method (Table 2).

Table 2. Methods of price formation for MPP, used in foreign countries

\begin{tabular}{|c|c|c|c|c|c|}
\hline \multirow{2}{*}{ Method } & \multicolumn{4}{|c|}{ Countries } & \multirow{2}{*}{ Method characterization } \\
\hline & USA & $\mathrm{RF}$ & FRN & Poland & \\
\hline Fixed prices & + & + & & & The cost that is not discussed \\
\hline Cost recovery & + & + & & & $\begin{array}{l}\text { Impossible to determine expenditures, conduction of SRW and } \\
\text { RD\&T }\end{array}$ \\
\hline $\begin{array}{l}\text { The material incentive of } \\
\text { producers }\end{array}$ & + & & & & $\begin{array}{l}\text { Encouraging of producers to improve quality or reduce } \\
\text { production time }\end{array}$ \\
\hline Tender (market) method & & & + & & $\begin{array}{l}\text { The method can be used when a country has a choice between } \\
\text { producers of MPP. }\end{array}$ \\
\hline Estimated reward & & & & + & $\begin{array}{l}\text { Grounds on the design and estimate documentation of the } \\
\text { ordering party. }\end{array}$ \\
\hline Firm (fixed) remuneration & & & & + & The contractor cannot require an increase in the cost of work \\
\hline $\begin{array}{l}\text { Approximate price (a price } \\
\text { that is specified) }\end{array}$ & & + & & & $\begin{array}{l}\text { The absence of data, the period of which exceeds three years of } \\
\text { a technological cycle of the products' production or, if } \\
\text { necessary, conduction of RD\&T }\end{array}$ \\
\hline $\begin{array}{l}\text { Price, providing } \\
\text { compensation for actual } \\
\text { expenditures on production }\end{array}$ & & + & & & Provides compensation of actual costs on production \\
\hline Parametric method & & + & & & $\begin{array}{l}\text { Comparison of integrated indexes of the product and its } \\
\text { analogue }\end{array}$ \\
\hline Analogue method & & + & & + & Details about available analogues of this sample \\
\hline Engineering method & & + & & & $\begin{array}{l}\text { Detailing of expenditures of engineering, operational, and } \\
\text { repair documentation, statements about the cost of component } \\
\text { parts and their operational lifetime }\end{array}$ \\
\hline Actual estimate method & & + & & & $\begin{array}{l}\text { Grounds on actual data, regarding expenditures with } \\
\text { consideration of such factors as inflation and changes in } \\
\text { taxation, the cost of the lost opportunities, etc. }\end{array}$ \\
\hline
\end{tabular}

Source: compiled by the author based on the data of the Official website of the Department Of Homeland Security USA

Thus, each country uses its individual methods of price formation for MPP, and, in the author's opinion, the methods, used for price formation depend on the following factors: the degree of development of the military industry; the availability of competition for the production of MPP; the volume of the produced MPP; the number of the internal and external MPP consumers; the degree of wear and tear of the main funds of the MPP producing enterprises; the form of ownership of the MPP producing enterprises. Each of these factors influences the choice of method of price formation and the cost of MPP. 
ENTREPRENEURSHIP AND SUSTAINABILITY ISSUES

ISSN 2345-0282 (online) http://jssidoi.org/jesi/

2021 Volume 8 Number 3 (March)

http://doi.org/10.9770/jesi.2021.8.3(28)

Make your research more visible, join the Twitter account of ENTREPRENEURSHIP AND SUSTAINABILITY ISSUES: @Entrepr69728810

As we can see from Table 2, there are countries (the USA, Germany, and Poland), which use a full set of the MPP cost assessment models.

In general, their approached ground on consideration of interests and risks of the ordering party and conductor, providing efficiency of use of the budget costs at all stages of design, production, and sales of MPP.

The United States Department of Defence uses contracts of different forms and purpose, including the contracts with fixed prices, remuneration of the production expenditures, and the material incentives of producers.

Germany gives its preference to tender (market) method of the DMG price formation. Poland uses the methods of estimated or firm (fixed) remuneration or both methods simultaneously.

The UK and other developed countries have a fairly strict system of government regulation in the area of DMG production in the interests of military-technical cooperation (MTC). The non-economic factors put some pressure on the price of DMG export supplies. Among them are primarily political factors, which affect not only the price itself but also the model of calculations for the products supplied. These factors play an important role and are used by all players in the DMG market.

The principle of export prices formation in the USA for new military products, the base of which is the cost of DMG delivery for the national armed forces. The law in the USA prohibits the export of DMG at prices lower than the domestic prices. Given the fact that the production of weapons in the US is many times higher than that of all other manufacturers, this requirement is understandable.

A large number of factors are taken into account when determining the contractual price of goods by a particular business. Depending on the chosen price formation strategy, the enterprise accepts the prices of the competitor firms to a greater or lesser extent.

Under the condition, when the amount of profit of the enterprise depends on the level of expenses, it is possible to get the contractor interested only when he makes a profit, no less than it was before expenditures reduction.

The expenditures reduction is advantageous for both the enterprise and the state. First of all, it increases the competitiveness of the state in the foreign markets; secondly, it provides an opportunity to transform a part of economic expenditures into profit, provides the enterprise with free financial resources for modernization of the main funds, innovation and social activity, which positively affects the quality of products, and will help to hold down the price for orders in the future.

The concise comparative characteristic of the expenditure and value-based concept of price formation is given in Table 3. 
ENTREPRENEURSHIP AND SUSTAINABILITY ISSUES

ISSN 2345-0282 (online) http://jssidoi.org/jesi/

2021 Volume 8 Number 3 (March)

http://doi.org/10.9770/jesi.2021.8.3(28)

Make your research more visible, join the Twitter account of ENTREPRENEURSHIP AND SUSTAINABILITY ISSUES: @Entrepr69728810

Table 3. Comparative characteristic of expenditure and value-based concept of price formation

\begin{tabular}{|c|c|c|}
\hline $\begin{array}{l}\text { Typical features of } \\
\text { comparison }\end{array}$ & Cost concept of price formation & Value-based concept of price formation \\
\hline Content & $\begin{array}{l}\text { Determination of the order price based on the } \\
\text { calculation of expenses and profit of the } \\
\text { contractor with consideration of the limit price of } \\
\text { the ordering party }\end{array}$ & $\begin{array}{l}\text { Combination of the customer's interests in the effective } \\
\text { military and economic use of the budgetary funds and the } \\
\text { interests of the contractor in the financial and economic } \\
\text { attractiveness of the order. } \\
\text { Determination of the price not only based on the costs but } \\
\text { depending on the quality (value) of MPP for the customer, } \\
\text { taking into account the effect of its intended purpose and } \\
\text { costs throughout the life cycle of MPP. }\end{array}$ \\
\hline Distinctive features & $\begin{array}{l}\text { The use of the "hard" price models: a fixed cost } \\
\text { and its varieties. } \\
\text { Strict peg of the price to the requirements of the } \\
\text { technical task for the ordered object. }\end{array}$ & $\begin{array}{l}\text { The use of "flexible" price models with components of } \\
\text { economic incentives of the Contractor for costs reduction, } \\
\text { the introduction of innovations, the MPP quality } \\
\text { improvement, risk insurance, etc. } \\
\text { Simplification of the balance search between the ordering } \\
\text { party and the contractor. }\end{array}$ \\
\hline Distinctive problems & $\begin{array}{l}\text { The weakness of the mechanism of reducing } \\
\text { performer costs and optimization of customer } \\
\text { investments. Binding of orders to individual } \\
\text { stages of the life cycle of the MPP. It does not } \\
\text { fully comply with the peculiarities of the } \\
\text { development of promising high-tech and } \\
\text { knowledge-intensive products with financial, } \\
\text { economic, and technological risks. }\end{array}$ & $\begin{array}{l}\text { For Ukraine - need for review and advancement (creation } \\
\text { of the new one) of the normative and methodological basis. }\end{array}$ \\
\hline $\begin{array}{l}\text { Current state and } \\
\text { perspectives for } \\
\text { application }\end{array}$ & $\begin{array}{l}\text { Dominates in Ukraine, keeps on functioning in } \\
\text { other countries alongside the application of the } \\
\text { elements of the value concept. } \\
\text { Gradual reduction of application especially for } \\
\text { knowledge-intensive and high-tech products with } \\
\text { a long life cycle. }\end{array}$ & $\begin{array}{l}\text { In the leading countries - as an object of application, } \\
\text { constant development and advancement, especially for } \\
\text { MPP, has trends to transition into dominating in the global } \\
\text { MPP market. } \\
\text { In Ukraine - as an object of understanding, theoretical } \\
\text { interest, and initial discussion. }\end{array}$ \\
\hline
\end{tabular}

Source: systematized by the author

Thus, an important feature and advantage of the value-based approach to pricing is the interrelation of MPP value indicators for the customer with his costs, which, firstly, stimulates those who carry out the order to improve MPP and increase its competitiveness, and, secondly, excludes price increases that are not related to improving the quality of the sample.

It should be noted that the transition from a cost to a value-based pricing system requires a review of the entire regulatory framework and, most importantly, the creation of a methodological (instructional and methodological) framework that will make it possible to obtain a correlation between the MPP value estimates and the quality (effect) and possible risks of its creation. There is a need for the development of clear methods for the practical application of various price models and reviewing of the price structure. 
ENTREPRENEURSHIP AND SUSTAINABILITY ISSUES

ISSN 2345-0282 (online) http://jssidoi.org/jesi/

2021 Volume 8 Number 3 (March)

http://doi.org/10.9770/jesi.2021.8.3(28)

Make your research more visible, join the Twitter account of ENTREPRENEURSHIP AND SUSTAINABILITY ISSUES: @Entrepr69728810

The implementation of the new pricing concept is comprehensive, not only in terms of the aspects of pricing taking into account the interests of the state but also in terms of realizing the interests of business entities. The transition to the new pricing concept will make it possible to significantly improve the quality of the plan documents, which are developed, the efficiency of budget allocations, and the financial stability of enterprises.

\section{Discussion}

The real-world effects in the area of international trade of DMG create certain conditions for suppliers and consumers: on the one hand, each country tries to arm its own army with modern DMG, including the one of foreign production, and, on the other hand, find and allocate funds for the development of its own defence industry.

When compared to the leading countries in the region, Ukraine is characterized by a range of differences in the defence industry, in particular:

- total lag of Ukraine in the defence industry (problems of the Armed Forces (AF) reformation, re-equipment, restructuration of the national DIC, etc.);

- a chronic lack of financing in the defence sphere and a disbalance of the defence budget towards "maintenance and capital decumulation."

Thus, the Ukrainian Armed Forces have such conditions, when the Ukrainian DIC is unable to produce modern DMG systems and will have to buy them abroad. The world experience shows that the most effective economic tool under such conditions is the use of the offset schemes during import of DMG for the development of DIC.

The offsets, under which the weapons salesman is obliged not only to deliver the goods but also takes additional responsibilities on the compensation of a share of his costs to a buyer, are widely used in international militarytechnical cooperation. These are the directions for the development of the international military and technical cooperation today. The offset opens up significant prospects under the limited financial capabilities for purchasing modern equipment and new technologies, improvement of its own military-industrial complex and attraction of foreign investments into the domestic market for the development of industries, which are not related to the defence industry.

More than 90 countries apply offset in various forms in the defence industry. Initially, the level of offset obligations amounted 10-20\% of the volume of the main export/import contract for the supply of DMG. Nonetheless, over time, as the global arms market began to shrink and supply started to exceed the demand, the requirements of the importers to volumes of compensation significantly increased.

The external factors, encouraging offset practice, include:

- the absence of the closed cycles of military machinery production;

- exhaustiveness of the design, technological, and technical developments, created in the DIC during the previous years against the background of almost no financing of the national innovative scientific and technical projects both military and civil ones;

- uncertainty of mechanisms and imperfection of the regulatory and legal framework for crediting the development of high technologies, provision of the intellectual property rights use;

- steady rise in the competition level in the global arms market, which provides the DMG importers with a diverse choice of means for putting pressure on the DMG exporters;

- the development of integration processes in the world economy, especially military-industrial sectors. 


\section{ENTREPRENEURSHIP AND SUSTAINABILITY ISSUES}

ISSN 2345-0282 (online) http://jssidoi.org/jesi/

2021 Volume 8 Number 3 (March)

http://doi.org/10.9770/jesi.2021.8.3(28)

Make your research more visible, join the Twitter account of ENTREPRENEURSHIP AND SUSTAINABILITY ISSUES: @Entrepr69728810

One keeps on performing the offset transactions in the context of the military-technical cooperation between the states, and the requirements for such agreements are becoming more responsible and detailed. The weaponimporting countries improve their legal framework on the conclusion and implementation of the offsets agreements. There is a global trend when the main contracts on the import of weapons and offset agreements join together. Herewith, the importing countries are trying to establish joint production on their own territory.

Offset is a modern practice in the international weapons and military equipment trade. It allows importers to partially compensate (in various forms) their own purchasing costs. In other words, offset is understood as a special agreement, under which the exporter takes an obligation to compensate the importer, in a way agreed with it, a part of the costs, related with purchasing military products. That is why such contracts are often regarded as compensation contracts.

The projects upon the following directions can turn into real offset programs in Ukraine:

- the establishment of service centres on collection and production, service and repair of the military purpose products, which are imported, in the home territories;

- the establishment of the production facilities on the modernization of the existing DMG, which is currently on service in the Armed Forces, as well as the production of specific types of spare parts and components for the military products, which are imported and modernized;

- acquisition and introduction of military technologies, developments, and "know-how";

- conduction of joint scientific research, research and design, production and technological, and other works;

- implementation of training and retraining programs for specialists of different fields of activity for the importing countries;

- investments in scientific organizations and production enterprises of the Ukrainian DIC and civil industries, which are of particular significance for the national security.

The priorities for military and technical cooperation in Ukraine should be as follows:

- the development of scientific and technical and production cooperation of defence enterprises with foreign companies;

- introduction of offset and leasing into the practice of export/import of defence products;

- joint use of existing military objects and construction of the new ones;

- lobbying of measures of the military and technical partnership of Ukraine with foreign countries at the state level, the advancement of information support and exhibition activities.

Ukraine has already started to create a legislative basis for work in the direction of implementation of the offset schemes during import of DMG. One has already approved the amendments to the Law of Ukraine "On State Defence Order," which introduce new notions of the compensation (offset) contract and terms of its application to the legislation of Ukraine, as well as the peculiarities of purchasing products, works, and services of defence purposes upon import.

According to this Law, the receiving of compensation is carried out through conclusion of a compensation (offset) agreement between the central executive body, authorized by the Cabinet of Ministers of Ukraine, and a foreign economic entity of a compensation (offset) agreement, which is a foreign economic agreement (contract). The implementation of the agreement is carried out following the terms of the state contract for supply and purchase of products, works, and services. 


\section{ENTREPRENEURSHIP AND SUSTAINABILITY ISSUES}

ISSN 2345-0282 (online) http://jssidoi.org/jesi/

2021 Volume 8 Number 3 (March)

http://doi.org/10.9770/jesi.2021.8.3(28)

Make your research more visible, join the Twitter account of ENTREPRENEURSHIP AND SUSTAINABILITY ISSUES: @Entrepr69728810

\section{Conclusions}

The results of the author's express diagnostics of financial security condition of 12 Ukrainian defence enterprises (3 non-governmental enterprises (private), 9 - state enterprises), held based on their statistical data (upon the data available as of 01.01.2019) show that with the beginning of the hybrid war against Ukraine, the state defence enterprises have significantly improved the level of their financial security due to growth of state financing of the production/repair of weapons and military machinery: almost all of the enterprises under the study in 2016-2017 reached high and satisfactory levels.

In general, in the group of state enterprises of the defence industry, one traces the influence of the extent of application of active cooperation by the enterprises with the external environment (increase in the number of the export and import contracts with order parties, the establishment of partnerships with suppliers and consumers, lobbying in relations with the state, etc.) on the level of their financial security. Different levels of financial security at the enterprises under consideration result from their industry specificity, which ha differences in the legal regulation of the industry, existing business practices, organizational peculiarities of the enterprises, technological peculiarities of production (in particular, the availability and complexity of cooperative relationships), market demand, and modern needs of the Armed Forces of Ukraine, the degree of state regulation of activity, etc.

In general, there is a positive trend in the group of private enterprises of the Ukrainian defence industry to increase in their active participation in the production of defence products (which is a worldwide trend), including using the state defence order, which improves their financial situation and enhances financial security. Alongside this, there is a direct dependence of the state of financial security of these companies on their management level and the ability for a preventive response to the changes in the external environment, including, through the establishment of productive cooperation with its subjects.

Thus, the interrelation of the DMG value indicators for the client with his expenditures is an important peculiarity and advantage of the value-based approach to the price formation. This, first of all, stimulates executors to advance DMG and improve its competitiveness; secondly, the cost increases, related to the sample's quality improvement, are excluded.

The real-world effects in the area of international trade of DMG create certain conditions for suppliers and consumers: on the one hand, each country tries to arm its own army with modern DMG (including the one of foreign production), and, on the other hand, find and allocate funds for the development of its own defence industry. The Ukrainian Armed Forces have such conditions when the Ukrainian DIC is unable to produce the necessary DMG systems and will have to buy them abroad. The most effective economic tool under such conditions is the use of the offset schemes during import of DMG for the development of DIC and strengthening of financial security of defence industry enterprises.

The offsets, under which the weapons salesman is obliged not only to deliver the goods but also takes additional responsibilities on the compensation of a share of his costs to a buyer, are widely used in international militarytechnical cooperation. The offset opens up significant prospects under the limited financial capabilities for purchasing modern equipment and new technologies, improvement of its own military-industrial complex and attraction of foreign investments into the domestic market for the development of the industry.

Ukraine does not yet have a state body, which carries out coordination and expert functions in the course of development of the offset query packages, as well as organizational and administrative and control functions 
ENTREPRENEURSHIP AND SUSTAINABILITY ISSUES

ISSN 2345-0282 (online) http://jssidoi.org/jesi/

2021 Volume 8 Number 3 (March)

http://doi.org/10.9770/jesi.2021.8.3(28)

Make your research more visible, join the Twitter account of ENTREPRENEURSHIP AND SUSTAINABILITY ISSUES: @Entrepr69728810

during the implementation of the offset programs (the Offset Commission, established under the Ministry of Economic Development, Trade and Agriculture of Ukraine cannot cover the entire scope of works on this question).

It was determined that the main efforts of the state, regarding the provision of favourable conditions for the implementation of the offset projects in the defence sector of Ukraine, should focus on:

- the development and implementation of the offset programs, which contribute to the development of the scientific and technological and production and technological potential of the country, transfer of modern technologies and know-how, an increase in labour productivity, a decrease in the resource and material consumption of the domestic products, and an improvement of their quality;

- acceleration of organizational changes in the national economy, directed at the creation of powerful integrated research and production structures, capable of developing and producing competitive MPP independently or in cooperation with foreign companies, in particular, EU countries;

- the development of international cooperation, including active participation in the activity of transnational corporations, conquering own segments of the world market during the international division of labour, cooperation in research and development works on creation of modern pieces of armament and military equipment;

- provision of the investment attractiveness of the defence enterprises;

- the development of the export-import activity of the enterprises of the national DIC and development and implementation of the effective organizational and economic mechanisms on the realization of foreign economic activity, the development of cooperation with foreign corporations for joint promotion products into the world markets;

- active introduction and use of modern information technologies in marketing and creation of the military and civilian purpose products.

\section{References}

About the statement of the Order of formation of the price for production, works, services of defense appointment in case selection of executors on supply (purchase) of such production, works, services is carried out without application of competitive procedures (2016). Available at: https://zakon.rada.gov.Ua/laws/show/517-2016-\%D0\%BF

About the statement of the Order of formation of the price for production, works, services of defense appointment in case selection of executors on supply (purchase) of such production, works, services is carried out without application of competitive procedures (2016).

Available at: https://zakon.rada.gov.ua/laws/show/517-2016-п?lang=en\#Text

Avanesova, N.E., Kolodyazhna, T.V., \& Semenova, J.I. (2018). Strategic platform for economic developmentof enterprises of the militaryindustrial complex of Ukraine. Naukovyi visnyk Uzhhorodskoho natsionalnoho universytetu, 20(1), 6-9. Available at: http://www.visnykeconom.uzhnu.uz.ua/archive/20_1_2018ua/3.pdf

Behma, V.M., \& Sverhunov, O.O. (2019). Conceptual bases of the strategies of investment-innovative development of the defenseindustrial complexes of the states. Experience for Ukraine. Kyiv: NISD, 64p. Available at: https://niss.gov.ua/sites/default/files/201907/Dopovid_Begma_druk.pdf

Kamianetska, O. (2015). Status and prospects of development of the military-industrial complex of Ukraine in the formation of national sovereignty. Visnyk Donetskoho natsionalnoho universytetu. Seriia V. Ekonomika i pravo, 1, 143-146. Available at: http://jvestnikc.donnu.edu.ua/article/view/291/302 


\section{ENTREPRENEURSHIP AND SUSTAINABILITY ISSUES}

ISSN 2345-0282 (online) http://jssidoi.org/jesi/

2021 Volume 8 Number 3 (March)

http://doi.org/10.9770/jesi.2021.8.3(28)

Make your research more visible, join the Twitter account of ENTREPRENEURSHIP AND SUSTAINABILITY ISSUES: @Entrepr69728810

Kravchenko, V. (2019). Military economics and military finance: new challenges in the first half of XXI century. Ekonomika ta derzhava, 9, 4-11. Available at: https://doi.org/10.32702/2306-6806.2019.9.4

Liao, H., Long, Y., Ming, T., Mardani, A., Xu, J. 2019. Low Carbon Supplier Selection Using a Hesitant Fuzzy Linguistic SPAN Method Integrating the Analytic Network Process. Transformations In Business \& Economics, Vol. 18, No 2 (47), pp.67-87.

Lincényi, M., Čársky, J. 2020. Policy trusts in public policy in the Slovak Republic. Insights into Regional Development, 2(1), 456-468. http://doi.org/10.9770/IRD.2020.2.1(5)

Lonsdale, D.J. (2019). The 2018 Nuclear Posture Review: A return to nuclear warfighting? Comparative Strategy, 38, 98-117. Available at: https://doi.org/10.1080/01495933.2019.1573074

Momot, T.V., Avanesova, N.E., \& Vinnik, I.U. (2015). The defense industry of Ukraine: priority directions of reform in the conditions of Eurointegration. Ekonomika i rehion, 5(54), 27-33.

Nzeribe, S., \& Imam, M. (2018). The military industrial complex: a catalyst for conflicts and wars (USA). Journal of Social Development, 7 (1), 73-81. Available at: https://doi.org/10.12816/0046772

Official website of the Department Of Homeland Security USA. URL: https://www.dhs.gov/cisa/defense-industrial-base-sector

Plèta, T., Tvaronavičienè, M., Della Casa, S., Agafonov, K. 2020. Cyber-attacks to critical energy infrastructure and management issues: overview of selected cases. Insights into Regional Development, 2(3), 703-715. https://doi.org/10.9770/IRD.2020.2.3(7)

Potomkina, M. (2018). Theoretical and legal foundations of economic legal relations in the defense industry of Ukraine. Part One. Pidpryiemnytstvo, hospodarstvo i pravo, 2, 58-62. Available at: http://pgp-journal.kiev.ua/archive/2018/2/12.pdf

Qureshi, F.A. (2018). The Military Industrial Complex and its typology in the context of its political framework. International Journal of Political Science and Development, 6(5), 123-130. Available at: https://doi.org/10.14662/IJPSD2018.035

Rajnoha, R., Lesnikova, P., Stefko, R., Schmidtova, J., Formanek, I. 2019. Transformations in Strategic Business Planning in the Context of Sustainability and Business Goals Setting. Transformations In Business \& Economics, Vol. 18, No 2(47), 44-66.

Reznik O., Mazievich T., Shebanits D., Puzanova G., Pyrih I. (2020). Peculiarities of Ecological Taxation in Ukraine and the World. Journal of Legal, Ethical and Regulatory Issues 23(1), c. 1-6. Available at: https://www.abacademies.org/articles/peculiarities-ofecological-taxation-in-ukraine-and-the-world-9016.html

State Statistics Service of Ukraine. Available at: http://www.ukrstat.gov.ua/

Tvaronavičienė, M., Plèta, T., Della Casa, S., Latvys, J. 2020. Cyber security management of critical energy infrastructure in national cybersecurity strategies: cases of USA, UK, France, Estonia and Lithuania. Insights into Regional Development, 2(4), 802-813. http://doi.org/10.9770/IRD.2020.2.4(6)

Usachenko, O. (2019). Experience of state regulation of the reform of the US and EU defense industrial complex. Derzhavne upravlinnia: udoskonalennia ta rozvytok, 7. Available at: https://doi.org/10.32702/2307-2156-2019.7.24

Weber, R.N. (2020). Military-industrial complex. Encyclopedia Britannica. Available at: https://www.britannica.com/topic/private$\underline{\text { military-firm }}$

YouControl system is an online service. Available at: https://youcontrol.com.ua/en/ 


\section{ENTREPRENEURSHIP AND SUSTAINABILITY ISSUES}

ISSN 2345-0282 (online) http://jssidoi.org/jesi/

2021 Volume 8 Number 3 (March)

http://doi.org/10.9770/jesi.2021.8.3(28)

Make your research more visible, join the Twitter account of ENTREPRENEURSHIP AND SUSTAINABILITY ISSUES: @Entrepr69728810

Oleksandr ILCHENKO, Candidate of Juridical Sciences, Associate Professor, Sumy State University

ORCID ID: orcid.org/0000-0003-4885-2205

Oksana BRUSAKOVA, Candidate of Philosophy, Associate Professor, Kharkiv National University of Internal Affairs

ORCID ID: orcid.org/0000-0001-6522-8020

Yuliia BURCHENKO, PhD student National University of Water Management and Nature Management

ORCID ID: orcid.org/0000-0002-9426-8280

Artem YAROSHENKO, PhD, Associate Professor, Dnipropetrovsk State University of Internal Affairs

ORCID ID: orcid.org/0000-0001-7072-0589

Yaroslav BAGAN, Lawyer, Law firm "Ex Jure"

ORCID ID: orcid.org/0000-0001-9509-6444

Copyright (C) 2021 by author(s) and VsI Entrepreneurship and Sustainability Center

This work is licensed under the Creative Commons Attribution International License (CC BY).

http://creativecommons.org/licenses/by/4.0/

(c) (i) Open Access 